Research.

\title{
THE INFLUENCE OF ORGANIZATIONAL CULTURE AND COMPENSATION ON ORGANIZATIONAL COMMITMENT WITH JOB SATISFACTION AS MEDIATION
}

\author{
Sudirman Widhy ${ }^{1}$, Hendro Yuliantoro², Muhammad Zulkarnain Azwar ${ }^{3}$, Anita \\ Maharani $^{4}$ \\ 1,2,3,4Binus Business School, Magister Management, Universitas Bina Nusantara \\ ${ }^{1 *}$ sudirman.hartono@binus.ac.id, ${ }^{2}$ hendro.yuliantoro@binus.ac.id, \\ ${ }^{3}$ muhammad.azwar@binus.ac.id, ${ }^{4}$ anita.maharani@binus.ac.id \\ ${ }^{*}$ Corresponding author
}

Received: October 14, 2021 Accepted: November 12, 2021 Published: December 31, 2021

To cite this article: Widhy, S; Yuliantoro, H; Azwar, MZ; Maharani, A.(2021). The Influence of Organizational Culture and Compensation on Organizational Commitment with Job Satisfaction as Mediation. The Management Journal Of Binaniaga, 6 (2), 165- 190 .doi: $10.33062 / \mathrm{mjb} . v 6 \mathrm{i} 2.465$

Abstract. The purpose of this research was to explore the possibility of the emergence of organizational commitment because of the influence of organizational culture and compensation on organizational commitment, in addition to being associated with job satisfaction as a mediation. The conceptual approach referred to in discussing this research starts from organizational commitment, organizational culture, compensation and job satisfaction. This research method can be explained as initially a quantitative approach, and because of the mediation the researcher refers to the structural model. The results of this research, among others, is that job satisfaction cannot be a mediation between organizational culture and organizational commitment and between compensation and organizational commitment. This then raises the picture that the respondents involved in this research do not see the presence of job satisfaction as an intermediary, interestingly, job satisfaction also does not affect organizational commitment. The results of this research have limitations, including only one company involved in the research and the company is categorized as high risk, so there is a possibility that the proposed hypothesis cannot reflect the picture in the company.

Keywords: Organizational Culture, Compensation, Organizational Commitment, Job Satisfaction

\section{INTRODUCTION}

\section{Background}

In the era of globalization, business competition that is increasing and getting tougher provides its own challenges for organizations. Of all available resources, organizations recognize that employees are their most valuable asset (Glen 2006; Govaerts et al. 2011; Sigler 1999). So that in order to remain competitive, the human resource management (HR) factor is the main key to organizational success (Silitonga et al. 2020). One aspect of employee performance that has attracted the attention of management and organizational researchers is organizational commitment. Scholars and researchers have investigated the effect of commitment on organizational efficiency (Grant 1991; King, Grace, and Funk 2013), the causal variables (Bateman and Strasser 1984; Clugston 2000; Decotiis and Summers 1987; Iverson and Roy 1994; Russ and McNeilly 1995; Taormina 1999) and how organizations can increase their employees' organizational commitment (Malhotra, Budhwar, and Prowse 2007; Mathieu and Zajac 1990; Meyer et al. 2002; Meyer and Parfyonova 2010; Porter et al. 1974; Trice et al. 1984). The issue of commitment is very important for a leader in the organization (Limerick et al., 1998;

Sudirman Widhy, Hendro Yuliantoro, Muhammad Zulkarnain Azwar, Anita Maharani. The Influence of Organizational Culture and Compensation on Organizational Commitment with Job Satisfaction as Mediation 
Tushman 1997). With the increasing speed and scale of change in organizations, organizational leaders are constantly looking for ways to generate higher employee commitment and competitive advantage (Lok and Crawford 2001). The issue of commitment is very important for a leader in the organization (Limerick et al., 1998; Tushman 1997). With the increasing speed and scale of change in organizations, organizational leaders are constantly looking for ways to generate higher employee commitment and competitive advantage (Lok and Crawford 2001). The issue of commitment is very important for a leader in the organization (Limerick et al., 1998; Tushman 1997). With the increasing speed and scale of change in organizations, organizational leaders are constantly looking for ways to generate higher employee commitment and competitive advantage (Lok and Crawford 2001).

The most influential impact on organizational commitment is job satisfaction, where a number of studies have shown a significant relationship between job satisfaction and this closely related but distinct commitment (Iverson and Roy 1994; Mathieu and Hamel 1989; Williams and Hazer 1986). Researchers such as Masia and Pienaar (2011), Sartono and Ardhani (2015), and Senjaya and Anindita (2020) have found a positive relationship between job satisfaction and organizational commitment to employees working in the mining industry in Indonesia. Employees will show a high commitment to the organization if they are satisfied with their work by carrying out their work responsibly, loyally, and proudly of their organization (Rojuaniah 2017).

According to Yiing and Ahmad (2009), leaders must realize that their success in influencing employees to achieve organizational goals depends on how they implement the organizational culture. The results of research by Acar (2012), Gokce, Guney, and Katrinli (2014), and Yildirim, Eventy, and Candan (2016) in Turkey revealed that organizational culture has a significant positive relationship with organizational commitment. Past research has shown to ensure employee commitment, companies often need to change the way they communicate with employees to create an organizational culture that respects people from all backgrounds, including different generations (Mehra and Nickerson 2019).

Compensation is the amount received by employees for services that have been provided to the company, compensation can be in the form of salaries, incentives, work benefits, gifts, and other facilities that are not in the form of money (Supriyadi, Sanusi, and Manan 2017). Likewise, as stated by Rianaa and Wirasedanaa (2016), compensation is one of the important things that must be given to employees to maintain employee commitment to stay involved in every company activity, employees who are highly committed will work to achieve competitive advantage and will maintain customer relationships. . Basher Rubel and Hung Kee (2015) and Makena Muguongo (2015) reveal that inadequate compensation is the main cause of employee dissatisfaction which can have other negative impacts on companies such as, not on target and absenteeism so that companies need to design better compensation. Research by Eliyana, Mardiana Yusuf, and Prabowo (2012) and Salisu, Chinyio, and Suresh (2015) revealed that compensation has a positive and significant effect on job satisfaction, this is because higher compensation will provide a stimulus to employees to work better than employees. at low compensation (Mabaso and Dlamini 2017).

A number of researchers suggest that job satisfaction is very important to understand the influence of various other variables on organizational commitment. Causal models of organizational commitment and turnover (Iverson and Roy 1994; Price and Mueller 1983; Williams and Hazer 1986) have suggested that the effects of various independent variables on commitment are mediated through job satisfaction. For example, Williams and Hazer (1986), using a causal modeling approach, concluded that various variables (i.e., age, pre-employment expectations, perceived job characteristics, and leadership style considerations dimensions) all influence commitment indirectly through their influence on job satisfaction. Similar results were obtained by Mathieu and (Hamel 1989) and Iverson and Roy (1994). However, Price and Mueller (1983) obtained slightly different results, they concluded that not all variables affecting the antecedents of commitment were mediated by job satisfaction. Other variables (eg, professionalism and family responsibilities) have a direct effect on commitment. In this research, the extent to

Sudirman Widhy, Hendro Yuliantoro, Muhammad Zulkarnain Azwar, Anita Maharani. The Influence of Organizational Culture and Compensation on Organizational Commitment with Job 
which job satisfaction can mediate a causal relationship between commitment to organizational culture variables and compensation will be investigated.

One possible antecedent of commitment that is relatively free from empirical investigation is organizational culture (Lok and Crawford 2001). For example, organizational culture was not included in the main review meta-analysis by Mathieu and Zajac (1990) of empirical research on the antecedents and correlations of commitment. Such omissions are surprising given the importance of culture in organizational writing (Alvesson and Sveningsson 2007; Brown 1995; Hofstede and Bond 1988; Sackman 1991; Towers 2006; Tushman 1997). Leading organizational culture writers such as Deal and Kennedy (1982) and de Ven, Peters, and Waterman (1983) have suggested that organizational culture can exert a considerable influence on organizational functioning, particularly in areas such as performance and commitment. Several studies, such as McCaul, Hinsz, and McCaul (1995) and Mueller, Wallace, and Price (1992) have addressed a similar issue by examining the effect of various employee values and beliefs. They found that there was a positive relationship between commitment and certain values and employees' beliefs in the organization. These findings highlight the need for further investigation of the relationship between organizational culture and commitment.

There are several studies, especially those conducted on organizations in the public sector and manufacturing in developing countries that show inconsistency in the relationship between compensation and job satisfaction and commitment. The results of Gamlath's (2019) research on 500 employees working in manufacturing export companies in the West Province, Sri Lanka revealed that compensation does not have a significant relationship to job satisfaction and organizational commitment. On the other hand, the results of Saman's (2020) research on 51 mining company employees show that the impact of compensation has a positive and significant effect on job satisfaction and employee performance.

According to the results of discussions and literature reviews in previous studies, one of the limitations in the literature is that it is not clear how exactly compensation and organizational culture can affect work commitment through job satisfaction of employees engaged in the mining sector in Indonesia. Second, we aim to provide one explanation of how job satisfaction can transmit the effects of organizational culture and compensation into employee organizational commitment in the coal mining industry.

According to the identification of the problems above, the question posed in this research is to examine the extent to which factors such as: organizational culture, compensation and job satisfaction can affect the organizational commitment of the coal mining industry. Meanwhile, the main objective of this research is to find out the factors that most influence organizational commitment and job satisfaction and can provide an overview of the company's strategies and steps to encourage increased commitment and job satisfaction of employees of the coal mining industry in Indonesia.

\section{LITERATURE REVIEW}

\section{Organizational Commitment}

Organizational commitment is one of the concepts that is widely discussed and researched, both as the dependent variable, independent variable, and mediator variable because it can describe the characteristics of employee behavior that are interesting to research (Rehman et al. 2012). According to Mathis and Jackson (2006), organizational commitment talks about the extent to which employees can accept and believe in the goals of the organization and have the desire to stay with and not leave the organization. Meyer and Allen (1997) in Mosadeghrad, Ferlie, and Rosenberg (2008) define organizational commitment as a psychological state that shows the characteristics of the relationship between employees and the organization and has an influence on the decision to continue membership in the organization. Literature studies have shown that there has been extensive research on organizational commitment over time (Mathieu and Zajac 1990; Meyer et al. 2002; Meyer and Parfyonova 2010; Porter et al. 1974; Trice et al. 1984). The positive effects of organizational commitment have been well recognized in

Sudirman Widhy, Hendro Yuliantoro, Muhammad Zulkarnain Azwar, Anita Maharani. The Influence of Organizational Culture and Compensation on Organizational Commitment with Job Satisfaction as Mediation 
the management literature. Commitment has been repeatedly identified in the organizational literature as an important variable in understanding employee work behavior in organizations (Meyer et al. 2002; Meyer and Herscovitch 2001; Mowday, Steers, and Porter 1979).

The results of previous research suggest that this commitment has an impact on several work-related attributes, such as intention to stay (Chew and Chan 2008; Mathieu and Zajac 1990; Meyer et al. 2002; Porter et al. 1974), absenteeism (Angle and Perry 1981).; Meyer et al. 2002; Porter et al. 1974), and job satisfaction (Natasha Fogaça and Francisco Antônio Coelho Junior 2016; Rojuaniah 2017; Yousef 2000). It is important for organizations to have committed employees in order to avoid high costs associated with high turnover and absenteeism rates (Chinomona and Dhurup 2014). In addition, committed employees are more likely to have higher work motivation and performance (Chen, Silverthorne, and Hung 2006; Rashid, Sambasivan, and Johari 2003; Riketta 2002; Samad 2005; Yousef 2000). To retain existing employees, companies can approach through human resource management that focuses on organizational commitment (Rubel et al. 2018). Organizations need a high commitment of employees to maintain consistent performance so as to increase competitiveness and productivity and ultimately result in higher profitability for the organization. In other words, employees who have a high work commitment are an important asset for the company to be able to achieve organizational goals optimally, effectively, and efficiently. Therefore, paying attention to several factors that can affect organizational commitment is very important for companies (Zayas-ortiz et al. 2015).

\section{Job Satisfaction}

The level of employee job satisfaction is the most important aspect that critically affects the success of the organization. Job satisfaction is directly related to individual happiness, because it reflects a positive relationship between work and life satisfaction (Bashir and Gani 2019). Robbins and Judge (2017) say that someone with a high level of job satisfaction has positive feelings towards his job which is shown in the form of loyalty. The general interpretation of this construct is reflected in Owsley and Linndrooth (2020), which defines job satisfaction as the attitude that individuals have about their work, which is the result of their perception of their job and the extent to which there is a good fit between the individual and the organization. A number of previous studies have demonstrated a strong relationship between job satisfaction and commitment which are closely related but distinct (Iverson and Roy 1994; Mathieu and Hamel 1989; Williams and Hazer 1986). Job satisfaction is an important determinant of employee job performance, organizational commitment, career mentoring, workplace attendance, and emotional intelligence (Sony and Mekoth 2016). In the same language, when employees' needs are met, their psychological well-being increases which allows for better functioning and performance, on the other hand, when employees do not get the expected experience, they fail to develop (Judge et al. 2001). Job satisfaction is an important determinant of employee job performance, organizational commitment, career mentoring, workplace attendance, and emotional intelligence (Sony and Mekoth 2016). In the same language, when employees' needs are met, their psychological well-being increases which allows for better functioning and performance, on the other hand, when employees do not get the expected experience, they fail to develop (Judge et al. 2001). Job satisfaction is an important determinant of employee job performance, organizational commitment, career mentoring, workplace attendance, and emotional intelligence (Sony and Mekoth 2016). In the same language, when employees' needs are met, their psychological well-being increases which allows for better functioning and performance, on the other hand, when employees do not get the expected experience, they fail to develop (Judge et al. 2001).

\section{Job satisfaction dynamic and organizational commitment}

Factors of job satisfaction and organizational commitment are interrelated with each other. According to Norris and Niebuhr (1984), job satisfaction refers to an effective response to the work environment, although organizational commitment is a more

Sudirman Widhy, Hendro Yuliantoro, Muhammad Zulkarnain Azwar, Anita Maharani. The Influence of Organizational Culture and Compensation on Organizational Commitment with Job 
constant and broader factor than job satisfaction. Even if employees may, even for a short time, become dissatisfied with their job/work, they still remain committed to the organization during the task. As stated by Gregson (1992), satisfaction is a symbol of the start of a person's commitment to his organization. Similarly, this finding is supported by Luthans (2012), which states that if employees are rewarded with job satisfaction, then a good commitment can be developed towards their respective organizations. Research of Johnson, Hornik, and Salas (2008) and Valaei, Rezaei, and Emami (2016), have confirmed a positive relationship between job satisfaction and organizational commitment. According to the positive evidence between organizational commitment and job satisfaction, we propose the following hypothesis:

\section{Organizational Culture}

Likewise with other organizational factors, over the years, organizational culture has been kept as a consideration (Peate 1966). It is considered a system of knowledge as well as standards that an employee acquires by observing and evaluating the organizational environment. After that, Uttal (1983) highlighted culture as "a system of shared values (what matters) and beliefs (how things work) that interact with organizational people, organizational structures and control systems to produce behavioral norms." Schein (2017) states that organizational culture can be interpreted as a pattern of general basic assumptions learned by groups to solve problems of internal integration and external adaptation,

\section{Organizational culture and organizational commitment}

Many scholars and organizational researchers have examined the relationship between corporate culture and commitment as a source of competitive advantage and have used many models to assess these two concepts and the relationship between organizational culture and organizational commitment (Mustafa, llyas, and Rehman 2016). Employees who view the culture in their organization as fair and respectful of their employees will have a higher level of organizational commitment. Yildirim et al. (2016), found that marketing organizational culture greatly influences affective commitment. Marketing culture creates a more participatory management within the organization and provides strong coordination between organizational goals and employees. When employees take part in strategic decisions or plans within the organization, they will become more loyal to the organization. Employees also feel more responsible and they try to solve organizational problems voluntarily in a market-oriented culture. It can be said that organizational culture has a positive effect on organizational commitment. Islam et al. (2013), also concluded that when employees in an organization are faced with a culture where they can learn continuously and are supported by their superiors, they show more commitment to the organization. Pickles (2012), Gokce et al. (2014), found that organizational culture has a positive relationship with organizational commitment. This is in accordance with research conducted by Sikorska-Simmons (2006) which says that organizational culture is a strong predictor of organizational commitment.

\section{Organizational culture and job satisfaction}

Organizational culture is included in the leading organizational values. These values are nurtured and developed by individuals within the organization that guide the organization's policies on employee management (Schein 2017). However, researchers such as Robbins and Coulter (2012) and Robbins et al. (2016) argue that organizational culture is largely the same as the existing rules in an organization. Organization members accept this rule. Under the same assumption, Robbins and Judge (2017) proposed that employees have subjective perceptions throughout the organization, which are According to objective factors, including the importance of work structure, emphasis on results, pressure on people, teams and aggressiveness and stability within the organization. Good and bad insights will then have an impact on employee job satisfaction which in fact affects the growth of the strength of organizational culture. Most of the research in this domain confirms the positive and significant influence of organizational culture on job satisfaction (Bigliardi et al. 2012; Ilham 2017; Sami et al. 2011; Shah, Memon, and

Sudirman Widhy, Hendro Yuliantoro, Muhammad Zulkarnain Azwar, Anita Maharani. The Influence of Organizational Culture and Compensation on Organizational Commitment with Job Satisfaction as Mediation 
Laghari 2011). According to the positive evidence between organizational culture and job satisfaction, we propose the following hypothesis:

\section{Compensation}

Compensation is most often considered as a key factor influencing employee satisfaction (Jalalkamali et al. 2016). Compensation refers to basic wages and additional wages such as overtime pay (Heery and Noon, 2001). It is generally known that money is an important instrument in meeting needs and salary satisfaction refers to how employees perceive payment compensation (Addis, Dvivedi, and Beshah 2018). These motivational factors attract a qualified workforce, retain employee talent, motivate and maintain the satisfaction of existing employees, and increase competition among employees to work hard and to achieve organizational and individual goals (Dulebohn and Werling 2007).

\section{Dynamics of Organizational Culture and Job Satisfaction}

Although satisfaction through compensation makes individuals feel valued which in turn results in stronger affective commitment (Lapointe, Vandenberghe, and Boudrias 2013), but money is not a driving factor, but rather a hygiene factor that may not always lead to satisfaction (Vincent et al. 1960). However, compensation remains a fundamental way by which organizations reward their employees. On the other hand, (McLean, Smits, and Tanner 1996) who studied the importance of payment compensation on the career attitude of IT professionals, found that initially salary was an important factor, but over time, other factors became more important than salary in increasing job satisfaction. work and work commitment. According to positive evidence between compensation and organizational commitment, we propose the following hypothesis:

\section{Dynamics of Compensation and Job Satisfaction}

Several researchers Adeoye and Elegunde (2014); Greene (2014), and Gupta and Shaw (2014) have determined that compensation and job satisfaction are positively related to each other. And job satisfaction can lead to motivation which in turn affects employee performance and organizational commitment. Bozeman and Gaughan (2011) show that the perception of being paid according to value predicts job satisfaction. They further stated that there is a significant positive relationship between compensation and job satisfaction. In another research conducted by Kennedy and Gray (2014), it was shown that compensation and benefits will affect employee job satisfaction. According to Hashim and Mahmood (2011), psychologists divide basic human needs into five levels according to Maslow's hierarchy of needs. From that perspective and personnel psychology, compensation can meet the physiological needs, safety and security, which consists of the first two levels, as well as employee needs for social interaction, selfesteem and self-actualization. Also, in a Research conducted on secondary school teachers in Kenya, it was concluded that teachers were very dissatisfied with all aspects of the compensation they received and determined that base salary, benefits and work environment affect teacher job satisfaction to a large extent (Makena Muguongo 2015). The discussion above, thus provides strong evidence to prove the relationship between compensation and employee job satisfaction. According to the positive evidence between compensation and job satisfaction, we propose the following hypothesis: and employees' needs for social interaction, self-esteem and self-actualization. Also, in a Research conducted on secondary school teachers in Kenya, it was concluded that teachers were very dissatisfied with all aspects of the compensation they received and determined that base salary, benefits and work environment affect teacher job satisfaction to a large extent (Makena Muguongo 2015). The discussion above, thus provides strong evidence to prove the relationship between compensation and employee job satisfaction. According to the positive evidence between compensation and job satisfaction, we propose the following hypothesis: and employees' needs for social interaction, self-

Sudirman Widhy, Hendro Yuliantoro, Muhammad Zulkarnain Azwar, Anita Maharani. The Influence of Organizational Culture and Compensation on Organizational Commitment with Job 
esteem and self-actualization. Also, in a Research conducted on secondary school teachers in Kenya, it was concluded that teachers were very dissatisfied with all aspects of the compensation they received and determined that base salary, benefits and work environment affect teacher job satisfaction to a large extent (Makena Muguongo 2015). The discussion above, thus provides strong evidence to prove the relationship between compensation and employee job satisfaction. According to the positive evidence between compensation and job satisfaction, we propose the following hypothesis: concluded that teachers were very dissatisfied with all aspects of the compensation they received and determined that basic salary, allowances and work environment affect teacher job satisfaction to a large extent (Makena Muguongo 2015). The discussion above, thus provides strong evidence to prove the relationship between compensation and employee job satisfaction. According to the positive evidence between compensation and job satisfaction, we propose the following hypothesis: concluded that teachers were very dissatisfied with all aspects of the compensation they received and determined that basic salary, allowances and work environment affect teacher job satisfaction to a large extent (Makena Muguongo 2015). The discussion above, thus provides strong evidence to prove the relationship between compensation and employee job satisfaction. According to the positive evidence between compensation and job satisfaction, we propose the following hypothesis:

\section{Dynamics of Organizational Culture, Job Satisfaction, and Organizational Commitment}

According to the findings of several previous studies such as Iverson and Roy (1994); Price and Mueller (1983); and Williams and Hazer (1986), job satisfaction is very important to understand the influence of various other variables on organizational commitment. As per the causal model of organizational commitment and turnover, they have suggested that the effects of various independent variables including organizational culture on commitment are mediated through job satisfaction. To examine the mediating impact of job satisfaction in explaining the indirect impact of organizational culture on organizational commitment, we propose the following hypothesis:

\section{Dynamics of Compensation, Job Satisfaction, and Organizational Commitment}

According to Fiorillo and Nappo (2014), Joung et al. (2015), Locke (1976), job satisfaction is defined as a feeling of job satisfaction that forms attitudes about work. With regard to compensation, equality theory suggests that an employee will be satisfied with the job if he or she values the effort expended as being adequately rewarded with compensation. Similarly, if they compare their compensation with others and judge that they are being paid unfairly, feelings of dissatisfaction arise. Another interpretation is that the level of satisfaction in a position can be high or low According to the difference between what a person believes he or she should be paid, and what is actually being paid (Broderick and Lawler 1991; Lazarus and Lawler 1972; Lum et al. 1998). Employees are attracted to monetary compensation and this can be an important component in satisfaction levels as well as turnover options, and the latter indicates commitment and loyalty to one's organization (Pillay 2009). Studies have found that pay/compensation is used by employers as a key strategy to increase employee commitment and retention (Horwitz, Heng, and Quazi 2003; Mitchell and Lee 2001; Terera and Ngirande 2014). Thus, the implication of the reviewed studies is that compensation can influence one's level of job satisfaction, which, in turn, may mediate the impact on organizational commitment. To examine the mediating impact of job satisfaction in explaining the indirect impact of compensation on organizational commitment, we propose the following hypothesis:

According to Sinem Aydogdu, and Baris Asikgil (2011) job satisfaction affects the decision to stay or leave the organization. It is said that employees with a high level of job satisfaction tend to show a higher level of commitment, while employees who have low

Sudirman Widhy, Hendro Yuliantoro, Muhammad Zulkarnain Azwar, Anita Maharani. The Influence of Organizational Culture and Compensation on Organizational Commitment with Job Satisfaction as Mediation 
job satisfaction tend to exhibit behaviors that can harm the organization. According to Gunlu, Aksarayli, and Perçin (2010) the level of employee job satisfaction predicts their commitment. The findings of a number of previous studies (Iverson and Roy 1994; Mueller et al. 1992; Williams and Hazer 1986) indicate that the influence of organizational culture and transformational leadership variables on commitment is operated indirectly by the effect of these variables on job satisfaction levels.

According to the exposure of the literature review that has been submitted by the author. The author submits a research proposal as follows:

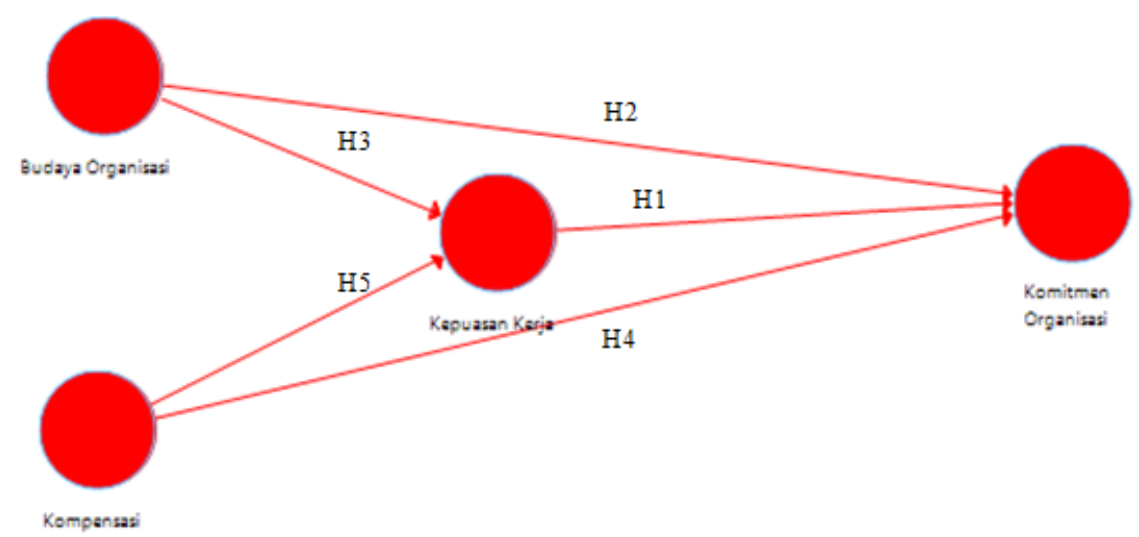

Figure 1. Research Model Proposal

\section{RESEARCH METHODS}

This research is a Quantitative Research designed to explain the influence between variables or the relationship that affects between variables through hypothesis testing (Eliyana, Ma'arif, and Muzakki 2019). This research uses a survey method to collect information from or about individuals to describe, compare, or explain knowledge, attitudes, and behavior (Fink 2002). The reason for choosing the survey method is that it can provide direction for the research process so as to allow planning the right way to help achieve the research objectives (Altinay and Paraskevas 2007). In researching a relationship, a quantitative survey research approach is conducted using statistical analysis to describe relationships and explain causal relationships (Puni, Mohammed, and Asamoah 2018).

Because the data collection is conducted at once in a certain period of time, in terms of the time horizon, the data collected in this research includes one-shot or crosssectional data (Sekaran Uma; Bougie Roger 2016). Organizational commitment and job satisfaction are a result of a naturally occurring process, so in research on this topic, exploratory and descriptive studies were conducted in unengineered research settings (Puni et al. 2018). In this research, the parameters and phenomena that affect job satisfaction and organizational commitment cannot be regulated by the researcher, so the level of interference with the research is relatively minimal.

The target population of this research is all employees of PT Arutmin Indonesia (PTAI) either permanent or contract from staff level to management spread over several work locations. PTAl employees are spread over 5 mining locations and 1 port location in 3 regencies of South Kalimantan province, 2 representative offices each in Banjarbaru and Balikpapan, and 1 head office in DKI Jakarta. However, in this research, outsourced employees who do not have a direct working relationship with PTAI are not included in the research object, because employees at this level do not enjoy the same benefits as PTAl employees. The selection of samples from this population refers to research

Sudirman Widhy, Hendro Yuliantoro, Muhammad Zulkarnain Azwar, Anita Maharani. The Influence of Organizational Culture and Compensation on Organizational Commitment with Job 
conducted by Ampofo (2020), where in the research conducted, there are elements from the population that are excluded to avoid bias in data processing. This research is a Causality Research to investigate the significance parameters of the relationship between the independent variables, namely transformational leadership, organizational culture, training, and compensation, mediating variables, job satisfaction and the dependent variable, organizational commitment.

The researcher will use a probabilistic sampling method, where all members of the population have the same opportunity to be selected to obtain data from this researcher. According to the population of respondents spread over several work areas, the researchers chose to use the cluster sampling method, where the sample came from groups with the same properties (Sekaran Uma; Bougie Roger 2016). Researchers will send questionnaires to PT Arutmin Indonesia employees spread over 5 mining locations, 1 port location, 2 branch offices, and 1 head office via email or google form. Regarding the selection of the observation unit, the respondents were employees of PT Arutmin Indonesia from entry level to management level. This sampling technique is used to ensure that a predetermined type of personnel requirement will be included in the sample. According to the Borg and Gall formula for determining sample size developed in 1973 used to determine sample size in this research as follows: $n=(\mathrm{Za}) 2(\mathrm{e})(\mathrm{N})$, where:

$$
\begin{aligned}
& \mathrm{n}=\text { sample size to be determined } \\
& \mathrm{N}=\text { the entire population of interest } \\
& \mathrm{e}=\text { acceptable margin of error? }=\text { level of significance }(0.05) \\
& \mathrm{Za}=\text { level of confidence }(1.960) \\
& \mathrm{n}=(1.96)^{2}(0.05)(400)=76.83
\end{aligned}
$$

The minimum sample size for this research was 77 employees of PT Arutmin Indonesia. Hair et al. (1998) stated that the minimum sample size with a variable 5 should be 100 or more. Thus, a minimum of 100 respondents was included as a sample in this research. In the sampling plan to be conducted, the number of samples from each cluster will be proportional to the number of employees at the work location, where the total area is represented by nine scattered areas. Then each selected region contributes a proportional number of samples to complete the minimum number of samples of at least 100 respondents.

The data collection method in this research plan is a survey in the form of a questionnaire conducted online through the google form platform. The online questionnaire method is used to obtain primary data easily and efficiently (Sekaran Uma; Bougie Roger, 2016). In addition, online questionnaires can also ensure the confidentiality of respondent data. The questionnaire formulated for this research consisted of two parts with questions - statements adapted from previous research. The first part of the questionnaire collects demographic information such as gender, age, and position in the organization. The second part consists of questions According to the questions used according to the literature from previous studies. In this research, the measurement of organizational culture variables was adopted from Hofstede \& Bond (1988) in research conducted by Mariam (2018) which included task orientation and internal organizational climate with 8 items, while the measurement of compensation variables was adopted from Tessema \& Soeters (2006) with 4 items, and the variable job satisfaction was adopted from Lambert \& Hogan (2009) and Luthans, (2012) with 4 items. Furthermore, the measurement of organizational commitment variable was adopted from Herscovitch \& Meyer (2002) as many as 12 items. While the scale of measurement using the Likert scale method. The Likert scale method uses five alternative answers, namely: a score of 5 means strongly agree, a score of 4 means agree, a score of 3 means between agree and disagree, a score of 2 means disagree and a score of 1 means strongly disagree (Joshi et al., 2015).

This research, to measure all variables, the researcher used a variance-based structural equation model (SEM) to analyze the data. We chose SEM, because it is the most powerful technique for testing models involving both direct and indirect effects (Kline 2015). This analysis builds convergence validity, constructs discriminant validity and

Sudirman Widhy, Hendro Yuliantoro, Muhammad Zulkarnain Azwar, Anita Maharani. The Influence of Organizational Culture and Compensation on Organizational Commitment with Job Satisfaction as Mediation 
examines the structural model. To establish convergent validity according to Henseler (2017), the following must be met: the indicator loading for each loading factor must be significant and greater than 0.70 Bahkia et al (2019); the mean of the extracted variance for each loading factor must be greater than 0.50 Fornell \& Larcker (1981); the minimum value of Cronbach Alpha is 0.70 and composite reliability for each loading factor must be greater than 0 .

After the convergence validity and discriminant validity were established, the structural model was used to evaluate the R2 value of the dependent variable to determine the model predictions according to the research of Koohang et al., (2017). Falk \& Miller (1992) assert that for any meaningful interpretation of the data, the R2 value must be at least 10 percent. Finally, the hypotheses are tested for acceptance or rejection. According to Chin (1998), the strength of the contribution of the independent variable to the dependent variable is determined by the standard path coefficient. Consequently, the t-value determines the acceptance or rejection of the hypothesis. Finally, the structural model examination will be tested using the NFI (Normed-fit Index) where according to Bentler (1990), the result interval limit where the model is considered fit is NFI $>0.9$.

\section{RESULTS AND DISCUSSION}

\section{Respondent Profile}

Respondents who participated in this research were 129 people with four categories, namely age, gender, position, and work location. According to gender, the respondents were dominated by 117 men or $91 \%$ while women were 12 people or $9 \%$. In terms of age, 55 people or $43.4 \%$ of respondents aged $31-40$ years were dominated by respondents, while the current job position category was dominated by 84 people or $65 \%$ of staff. From the distribution of work locations, our respondents on average have represented above $25 \%$ of the total population of employees at each work location with the largest number of respondents from the Batulicin site as much as $57 \%$ of the population.

\section{Construct Reliability and Validity Test}

SEM serves to validate the research model. The ability of SEM to test causal relationships constructs multiple measurement items. Structural equation modeling (SEM) is a technique that can handle different measurement models: composite, common factor, and causal-formative measurement (Henseler 2017). SEM clarifies the differences between these types of measurement models and clears up possible ambiguity regarding formative endogenous constructs (Henseler 2017). The PLS technique was used to evaluate the psychometric properties of the theoretical models and hypotheses. PLS is a structured equation modeling technique that evaluates how items fit into their constructs simultaneously by approximating all paths in the model (Akhtar et al. 2019)

Analyzing the relationship between constructs only if there is sufficient evidence of their validity and reliability (Henseler 2017). Validity test using convergent validity test and discriminant validity test. Convergent validity can be considered by calculating the loading factor and Average Variance Extracted (AVE). The research model was calculated using SMART PLS software, the loading factor was calculated and selected at least 0.7 . Meanwhile, the Average Variance Extracted (AVE) according to Henseler, (2017) must have a value higher than 0.5 because then there is no second factor that explains the variance as much as the first. The construction of this research model shows a convergent validity test that can be accepted because the loading factor is above 0.6 and the AVE is above 0.5. Table 1 shows the loading factor and mean variance extracted from the research model. Seven constructs (BO-II3, SAT4, KO2, KO5, KO6, KO8, and $\mathrm{KO11}$ ) had to be eliminated because the loading factor was less than 0.7 . After elimination, the remaining constructs have met all the reliability and validity test criteria as shown in the following table:

Sudirman Widhy, Hendro Yuliantoro, Muhammad Zulkarnain Azwar, Anita Maharani. The Influence of Organizational Culture and Compensation on Organizational Commitment with Job 
The Management Journal of BINANIAGA Vol. 06, No.02, December 2021 p-ISSN: $2527-4317$, e-ISSN: $2580-149 x$

$6^{\text {th }}$ Accreditation Rating: April 04, 2019-April 03, 2024

Table 1. Construct Reliability and Validity

\begin{tabular}{|c|c|c|c|c|c|c|c|c|c|}
\hline \multirow{2}{*}{ Variables } & \multirow{2}{*}{ Item } & \multicolumn{2}{|c|}{ Loading Factor } & \multicolumn{2}{|c|}{ AVE } & \multicolumn{2}{|c|}{ CR } & \multicolumn{2}{|c|}{ Cronbachs Alpha } \\
\hline & & Original & $\begin{array}{c}\text { if } \\
\text { Deleted }\end{array}$ & Original & $\begin{array}{c}\text { if } \\
\text { Deleted }\end{array}$ & Original & $\begin{array}{c}\text { if } \\
\text { Deleted }\end{array}$ & Original & $\begin{array}{c}\text { if } \\
\text { Deleted }\end{array}$ \\
\hline \multirow{8}{*}{$\begin{array}{l}\text { Organizational } \\
\text { Culture }\end{array}$} & BO- & 0.809 & 0.802 & \multirow{8}{*}{0.639} & \multirow{8}{*}{0.680} & \multirow{8}{*}{0.934} & \multirow{8}{*}{0.937} & \multirow{8}{*}{0.918} & \multirow{8}{*}{0.921} \\
\hline & $\begin{array}{l}\mathrm{BO}- \\
\mathrm{II} 2\end{array}$ & 0.886 & 0.884 & & & & & & \\
\hline & $\begin{array}{l}\text { BO- } \\
\text { II3 }\end{array}$ & 0.689 & Deleted & & & & & & \\
\hline & $\begin{array}{l}\text { BO- } \\
\text { I14 }\end{array}$ & 0.713 & 0.718 & & & & & & \\
\hline & $\begin{array}{l}\text { BO- } \\
\text { OT1 }\end{array}$ & 0.815 & 0.816 & & & & & & \\
\hline & $\begin{array}{l}\text { BO- } \\
\text { OT2 }\end{array}$ & 0.827 & 0.851 & & & & & & \\
\hline & $\begin{array}{l}\text { BO- } \\
\text { OT3 }\end{array}$ & 0.821 & 0.849 & & & & & & \\
\hline & $\begin{array}{l}\text { BO- } \\
\text { OT4 }\end{array}$ & 0.816 & 0.842 & & & & & & \\
\hline \multirow{4}{*}{ Compensation } & KOM1 & 0.842 & 0.847 & \multirow{4}{*}{0.693} & \multirow{4}{*}{0.693} & \multirow{4}{*}{0.900} & \multirow{4}{*}{0.900} & \multirow{4}{*}{0.849} & \multirow{4}{*}{0.849} \\
\hline & KOM2 & 0.879 & 0.882 & & & & & & \\
\hline & KOM3 & 0.877 & 0.875 & & & & & & \\
\hline & KOM4 & 0.721 & 0.715 & & & & & & \\
\hline \multirow{4}{*}{$\begin{array}{c}\text { Job } \\
\text { Satisfaction }\end{array}$} & SAT1 & 0.827 & 0.857 & \multirow{4}{*}{0.654} & \multirow{4}{*}{0.777} & \multirow{4}{*}{0.881} & \multirow{4}{*}{0.913} & \multirow{4}{*}{0.817} & \multirow{4}{*}{0.856} \\
\hline & SAT2 & 0.900 & 0.910 & & & & & & \\
\hline & SAT3 & 0.871 & 0.876 & & & & & & \\
\hline & SAT4 & 0.601 & Deleted & & & & & & \\
\hline \multirow{12}{*}{$\begin{array}{l}\text { Organizational } \\
\text { Commitment }\end{array}$} & KO1 & 0.780 & 0.787 & \multirow{12}{*}{0.559} & & & & & \\
\hline & $\mathrm{KO} 2$ & 0.652 & Deleted & & & & & & \\
\hline & KO3 & 0.786 & 0.816 & & & & & & \\
\hline & KO4 & 0.851 & 0.876 & & & & & & \\
\hline & KO5 & 0.695 & Deleted & & & & & & \\
\hline & $\mathrm{KO6}$ & 0.618 & Deleted & & & & & & \\
\hline & KO7 & 0.805 & 0.785 & & 0.659 & 0.938 & 0.931 & 0.921 & 0.973 \\
\hline & KO8 & 0.698 & Deleted & & & & & & \\
\hline & $\mathrm{KO9}$ & 0.780 & 0.814 & & & & & & \\
\hline & KO10 & 0.811 & 0.835 & & & & & & \\
\hline & K011 & 0.693 & Deleted & & & & & & \\
\hline & K012 & 0.737 & 0.762 & & & & & & \\
\hline
\end{tabular}

Source : SMART PLS result

Measurement of discriminant validity was conducted using Fornell Lacker criteria and cross loading. The Fornell Lacker criterion requires that the Average Variance Extracted (AVE) construct is higher than the quadratic correlation (Henseler, 2017).

Sudirman Widhy, Hendro Yuliantoro, Muhammad Zulkarnain Azwar, Anita Maharani. The Influence of Organizational Culture and Compensation on Organizational Commitment with Job Satisfaction as Mediation 
Table 2. Fornell Licker Criterion

Kompensasi Kepuasan Kerja Budaya Organisasi Komitmen Organisasi

\begin{tabular}{lcccc}
\hline Kompensasi & 0.832 & & & \\
Kepuasan Kerja & 0.599 & 0.881 & 0.825 & \\
Budaya Organisasi & 0.572 & 0.494 & 0.811 \\
Komitmen Organisasi & 0.659 & 0.546 &
\end{tabular}

Calculation of Cronbach's Alpha can be used to assess the reliability test of internal consistency. The recommended value for Cronbach's alpha is above 0.7. The research model was declared to have passed the Cronbach's Alpha test, as shown in Table 1. Internal consistency reliability quantifies the amount of random measurement error in the construct score that serves as a surrogate for latent variables. The consistent reliability coefficient for construct scores is Raykov's $r$ (Raykov 1997). If all the composite weights are equal, they will equal the reliability of the $\mathrm{RC}$ composite as proposed by (Werts et al. 1978). The recommended value for composite reliability is 0.7 . According to Table 1 , the composite reliability of the research model is above 0.7 which has passed the recommended value limit.

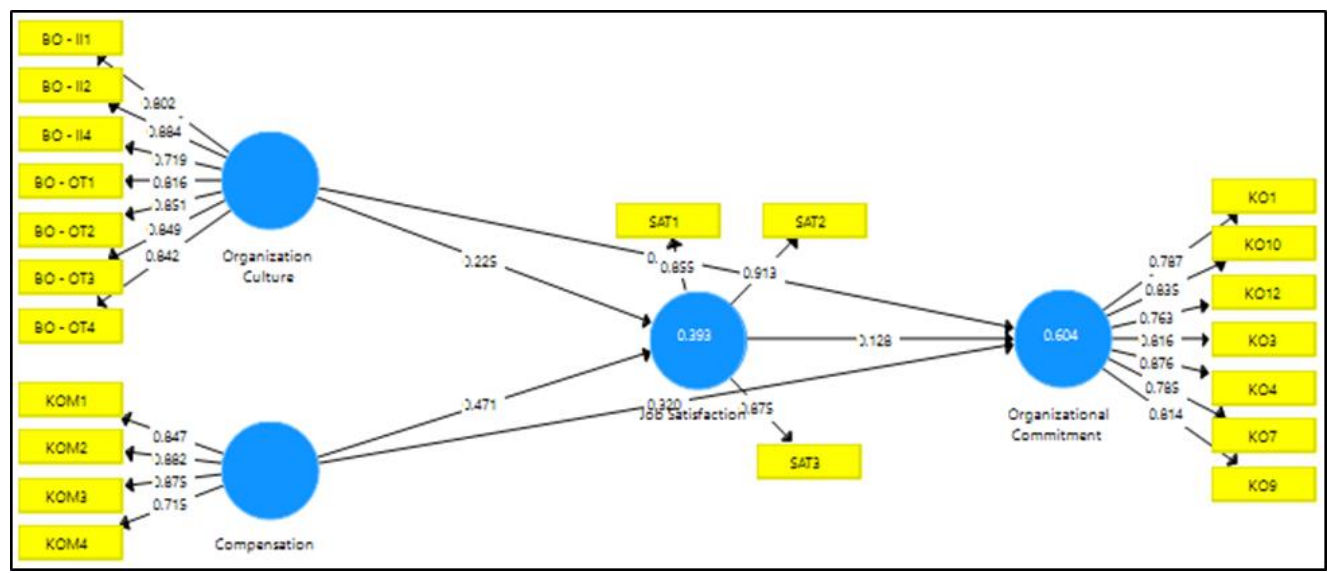

Source : SMART PLS result

Figure 1. Inner Model

\section{Assesment Structure and Model Fit}

The significance of the research model was tested using the bootstrap method with a significance level of 0.05 . If the T-statistic value $>1.96$ then the relationship between exogenous and endogenous variables is significant. If the $T$-statistic value $<1.96$, then the relationship between exogenous and endogenous variables is not significant. Our research model shows a T-statistic value $>1.96$ between variables, which means that each variable is substantial.

According to the research model in Figure 2, the results of hypothesis testing in this research are presented in the following table:

Table 3a. Research Model Hypothesis Testing

\begin{tabular}{lcccc} 
Hipotesis & $\begin{array}{c}\text { Original } \\
\text { Sample }(\mathrm{O})\end{array}$ & $\begin{array}{c}\text { T Statistics } \\
(\mid \mathrm{IO} / \mathrm{STDEV}\rfloor)\end{array}$ & $\begin{array}{c}\text { P Values } \\
\text { Kesimpulan }\end{array}$ \\
\hline Kepuasan Kerja -> Komitmen Organisasi (H1) & 0.128 & 1.406 & $\mathbf{0 . 1 6 0}$ & Tidak Didukung \\
Budaya Organis asi -> Komitmen Organisasi (H2) & 0.427 & 4.510 & $\mathbf{0 . 0 0 0}$ & Terdukung \\
Budaya Organisasi -> Kepuasan Kerja (H3) & 0.225 & 2.219 & $\mathbf{0 . 0 2 7}$ & Terdukung \\
Kompensasi -> Komitmen Organisasi (H4) & 0.32 & 2.890 & $\mathbf{0 . 0 0 4}$ & Terdukung \\
Kompensasi -> Kepuasan Kerja (H5) & 0.471 & 4.915 & $\mathbf{0 . 0 0 0}$ & Terdukung \\
\hline
\end{tabular}

Source : SMART PLS result

Sudirman Widhy, Hendro Yuliantoro, Muhammad Zulkarnain Azwar, Anita Maharani. The Influence of Organizational Culture and Compensation on Organizational Commitment with Job 
According to the $P$ Values as shown in table $3 a$ above, job satisfaction which has a mediating role is not proven to affect work commitment. The two independent variables of organizational culture and compensation have been shown to have direct effects on job satisfaction and organizational commitment respectively.

Table 3b. Research Model Hypothesis Testing

\begin{tabular}{lcccc}
\hline Hipotesis & $\begin{array}{c}\text { Original } \\
\text { Sample }(\mathrm{O})\end{array}$ & $\begin{array}{c}\text { T Statistics } \\
(\mid \mathrm{IO} / \mathrm{STDEV}\rfloor)\end{array}$ & P Values & Kesimpulan \\
\hline Budaya Organisasi -> Kepuasan Kerja -> Komitmen Organisasi (H6) & 0.029 & 1.092 & $\mathbf{0 . 2 7 5}$ & Tidak Didukung \\
Kompensasi $->$ Kepuasan Kerja $->$ Komitmen Organisasi (H7) & 0.06 & 1.340 & $\mathbf{0 . 1 8 0}$ & Tidak Didukung \\
\hline
\end{tabular}

Source : SMART PLS result

According to the results shown in table $3 b$., it is known that job satisfaction has no role as an indirect effect, both between organizational culture and organizational commitment, as well as between compensation and organizational commitment (PValues $>0.05$ ). Therefore, the results of testing using bootstrapping show that hypothesis 6 and hypothesis 7 are not supported.

Table 4. Model Fit

\begin{tabular}{ccc} 
& Saturated Model & Estimated Model \\
\hline NFI & 0.807 & 0.807 \\
& Source : SMART PLS result
\end{tabular}

To show the extent to which the model in this research can explain the phenomenon related to employee organizational commitment, it can be described by the fit model from Table 4. This table illustrates that this research model is able to explain the phenomenon related to organizational commitment of $80.7 \%$ in mining companies which are the object of research. this time.

The purpose of this research was to examine the effect of factors such as organizational culture and compensation on job satisfaction, and employee organizational commitment. To achieve such a goal, we developed a conceptual framework from the literature. According to this context, research models and hypotheses are then compiled and produced. This research uses a deductive approach According to cross-sectional data.

Job satisfaction is not related to organizational commitment. The findings of this research are quite interesting and seem to contradict the natural conditions and scientific studies that suspect that job satisfaction is a driver for organizational commitment. The job satisfaction factor is not proven to directly affect organizational commitment or as a factor that can mediate the relationship between organizational culture and compensation in shaping the organizational commitment of mining industry employees. The profile of the mining industry that has a high work risk and remote work locations is known to have a more competitive employee status policy and compensation rate compared to most other industries. It is suspected that compensation is one of the drivers in building organizational commitment and this is proven by the significant relationship between compensation and job satisfaction and organizational commitment in this research. In addition, the profile of research respondents who are employees of PT Arutmin spread across the site and branch offices of the company are dominated by staff and supervisors aged 31-50 years, it is suspected that they also contributed to this situation. Arutmin's relatively lean organizational structure is supported by the distribution of the age factor in the position that allows a staff and/or supervisor to occupy the same position for a long period of time. Each individual in the organization is accustomed to carrying out and completing work routines that are his area of responsibility, even with minimal communication and direction from direct superiors within the organization. These two things are thought to build the respondent's perspective that job satisfaction is not a driver

Sudirman Widhy, Hendro Yuliantoro, Muhammad Zulkarnain Azwar, Anita Maharani. The Influence of Organizational Culture and Compensation on Organizational Commitment with Job Satisfaction as Mediation 
for organizational commitment. Job satisfaction and organizational commitment are factors that do not influence each other and stand alone.

The significant finding of job satisfaction and organizational commitment can also be explained through a Previous Research conducted by Köse and Köse (2017) on 501 health workers working in public hospitals in Turkey. This research found that there was no statistically significant effect between intrinsic satisfaction on organizational commitment; only extrinsic satisfaction was found to have a significant negative effect on continuance commitment and positive effect on normative commitment. That is, extrinsic factors such as salary, promotion, supervision or working conditions are stronger for mining workers to generate commitment According to a feeling of obligation to the organization and a strong belief about being a member of the organization is a right or a moral thing to do. rather than internal factors such as skill use, job variety, and experience. If job satisfaction is more related to the business environment, organizational commitment is related to dependence on management, management policies and relationships with management.

Organizational culture is proven to have a relationship with job satisfaction and organizational commitment. This shows that a strong organizational culture will increase job satisfaction among mining industry employees. Companies in the mining industry generally emphasize teamwork to coordinate well in achieving company goals. The company also always provides opportunities to continue to think innovatively so that in the end it grows satisfaction with the work they have. There are several previous research results which state that organizational culture affects employee job satisfaction, namely ElKordy (2013); Lok and Crawford (2001); Lund (2003); Qazi, Miralam, and Bhalla (2017); and Rawashdeh, Al-Saraireh, and Obeidat (2015). A strong organizational culture in mining industry companies results in high agreement because of the shared values shared by members of the organization. This will foster a sense of belonging to employees. They are proud to be part of the organization and choose not to leave the organization thereby creating employee commitment to the organization. The results of this research are in line with the results of Acar (2012); Gokce et al. (2014); Islam, Khan, et al. (2013); Sikorska-Simmons (2006); Yildirim et al. (2016) who concluded that organizational culture has an effect on organizational commitment. They are proud to be part of the organization and choose not to leave the organization thereby creating employee commitment to the organization. The results of this research are in line with the results of Acar (2012); Gokce et al. (2014); Islam, Khan, et al. (2013); Sikorska-Simmons (2006); Yildirim et al. (2016) who concluded that organizational culture has an effect on organizational commitment. They are proud to be part of the organization and choose not to leave the organization thereby creating employee commitment to the organization. The results of this research are in line with the results of Acar (2012); Gokce et al. (2014); Islam, Khan, et al. (2013); Sikorska-Simmons (2006); Yildirim et al. (2016) who concluded that organizational culture has an effect on organizational commitment.

Organizations can further improve the implementation of organizational culture by providing opportunities for each employee to issue initiatives, ideas or ideas related to organizational development. Building continuous organizational commitment through superiors by instilling in each employee to always be responsible for both their work and the organization where they work, so that later it can improve in each employee a high sense of loyalty or commitment to the organization. Organizations in the mining industry to further improve compensation policies, both financial compensation and non-financial compensation that are competitive with other similar organizations that are adapted to the characteristics of the work environment such as remote areas, availability of public facilities and others. Likewise, a work assessment is needed that considers including job descriptions, workloads, responsibilities and appropriate levels of office, so as to create a fairness perspective and increase employee welfare. According to the discussion, it can be concluded that the most dominant variation in job satisfaction is directly influenced by organizational culture and compensation. Meanwhile, the variation of job satisfaction on organizational commitment does not affect either organizational culture or compensation. From this it can be seen that for mining workers, compensation and organizational culture

Sudirman Widhy, Hendro Yuliantoro, Muhammad Zulkarnain Azwar, Anita Maharani. The Influence of Organizational Culture and Compensation on Organizational Commitment with Job 
provide a significant relationship to job satisfaction which can build organizational commitment.

There are limitations in this research as in all studies. There may be a bias in the results of this research because data were obtained from only one mining company operating in South Kalimantan regarding the costs and time of surveys of employees of mining companies in another province. Furthermore, there is a possibility that respondents are not serious in filling out the questionnaire or only fill it out According to the expected ideal conditions, not the actual conditions that are happening. This research only discusses the variables of organizational culture, compensation, job satisfaction, and organizational commitment. In addition, this research does not have generalizability criteria, because the sample size is small and data is collected from several employees in one of the companies, there may be other components of job satisfaction that can predict changes in organizational commitment as well. Therefore, future research should consider other components of job satisfaction and research their relevance to organizational commitment. In addition, because the placement of employees in the Indonesian mining sector is divided into placements in the head-office and site-office, it is necessary to conduct further research by considering the factor of employee placement as a control variable to see the differences between different working environment conditions.

\section{CONCLUSION}

This research aims to determine the role of organizational culture and compensation on organizational commitment through job satisfaction in mining industry employees. The environmental characteristics of the mining industry are a challenge for employees because they have a fairly high level of difficulty to achieve maximum work results. Employees in the mining industry need direction and support from the leadership in creating a conducive organizational culture that fosters job satisfaction and also creates employee commitment to the mining industry.

There are practical and theoretical contributions that emerge from the findings of this research. One of the practical contributions of this research is that it highlights aspects of job satisfaction and aspects of organizational commitment in Indonesia. In addition, this is one of the few early studies in Indonesia to consider the relationship between job satisfaction and organizational commitment in Indonesian mining organizations. The results of this research help Companies to assess the level of job satisfaction among their employees. In fact, the practical contribution of this research is to reduce the associated risk and help companies to know the level of commitment of their employees and according to that, can propose policies to increase the level of job satisfaction and retain employees. Therefore, the results help companies in their efforts to reduce the loss of potential and talented employees.

The results of this research will be useful for practitioners in showing the extent to which mining employees are satisfied about their jobs from the perspective of organizational culture and compensation. Managers can observe the commitment level of their employees and plan to increase their commitment level through filling gaps that are difficult to deal with without supervision. It is recommended that mining managers and CEOs make the right decisions According to the results of this research to increase job satisfaction in terms of the pertinent aspects. The findings of this research will benefit the company because According to this research they can observe which factors are important from the point of view of mining employees in Indonesia regarding their organizational commitment.

Sudirman Widhy, Hendro Yuliantoro, Muhammad Zulkarnain Azwar, Anita Maharani. The Influence of Organizational Culture and Compensation on Organizational Commitment with Job 


\section{REFERENCES}

Acar, A. Zafer. (2012). "Organizational Culture, Leadership Styles and Organizational Commitment in Turkish Logistics Industry." Procedia - Social and Behavioral Sciences 58. doi: 10.1016/j.sbspro.2012.09.995.

Addis, Sisay, Akshay Dvivedi, and Birhanu Beshah. (2018). "Determinants of Job Satisfaction in Ethiopia: Evidence from the Leather Industry." African Journal of Economic and Management Studies 9(4):410-29. doi: 10.1108/AJEMS-09-20170222.

Adeoye, Abayomi Olarewaju, and Ayobami Folarin Elegunde. (2014). "Compensation Management and Motivation: Cooking Utensils for Organisational Performance." Mediterranean Journal of Social Sciences 5(27). doi: 10.5901/mjss.2014.v5n27p88.

Akhtar, Sadia, Kashif Ullah Khan, Shah Hassan, Muhammad Irfan, and Fouzia Atlas. (2019). "Antecedents of Task Performance: An Examination of Transformation Leadership, Team Communication, Team Creativity, and Team Trust." Journal of Public Affairs 19(2). doi: 10.1002/pa.1927.

Altinay, Levent, and Alexandros Paraskevas. (2007). Planning Research in Hospitality and Tourism.

Alvesson, Mats, and Stefan Sveningsson. (2007). Changing Organizational Culture: Cultural Change Work in Progress.

Angle, Harold L., and James L. Perry. (1981). "An Empirical Assessment of Organizational Commitment and Organizational Effectiveness." Administrative Science Quarterly 26(1). doi: 10.2307/2392596.

Bahkia, Ayu Suriawaty, Zainudin Awang, Asyraf Afthanorhan, and Puspa Liza. (2019). "Exploratory Factor Analysis on Occupational Stress in Context of Malaysian Sewerage Operations Exploratory Factor Analysis on Occupational Stress in Context of Malaysian Sewerage Operations." 050006(August).

Basher Rubel, Mohammad Rabiul, and Daisy Mui Hung Kee. (2015). "High Commitment Compensation Practices and Employee Turnover Intention: Mediating Role of Job Satisfaction." Mediterranean Journal of Social Sciences. doi: 10.5901/mjss.2015.v6n6s4p321.

Bashir, Barooj, and Abdul Gani. (2019). "Testing the Effects of Job Satisfaction on Organizational Commitment." Journal of Management Development 39(4):525-42. doi: 10.1108/JMD-07-2018-0210.

Bateman, T. S., and S. Strasser. (1984). "A Longitudinal Analysis of the Antecedents of Organizational Commitment." Academy of Management Journal. Academy of Management 27(1):95-112. doi: 10.2307/255959.

Bentler, P. M. (1990). “Comparative Fit Indexes in Structural Models." 107(2):238-46.

Bigliardi, Barbara, Alberto Ivo Dormio, Francesco Galati, and Giovanni Schiuma. (2012). "The Impact of Organizational Culture on the Job Satisfaction of Knowledge Workers." VINE 42(1). doi: 10.1108/03055721211207752.

Bozeman, Barry, and Monica Gaughan. (2011). "Job Satisfaction among University Faculty: Individual, Work, and Institutional Determinants." The Journal of Higher Education 82(2). doi: 10.1080/00221546.2011.11779090.

Sudirman Widhy, Hendro Yuliantoro, Muhammad Zulkarnain Azwar, Anita Maharani. The Influence of Organizational Culture and Compensation on Organizational Commitment with Job 
Broderick, Renae, and Edward E. Lawler. (1991). "Strategic Pay: Aligning Organizational Strategies and Pay Systems." Industrial and Labor Relations Review 45(1). doi: $10.2307 / 2524720$.

Brown, Andrew. (1995). Organisational Culture. London: Pitman Publishing.

Chen, Jui Chen, Colin Silverthorne, and Jung Yao Hung. (2006). "Organization Communication, Job Stress, Organizational Commitment, and Job Performance of Accounting Professionals in Taiwan and America." Leadership \& Organization Development Journal 27(4). doi: 10.1108/01437730610666000.

Chew, Janet, and Christopher C. A. Chan. (2008). "Human Resource Practices, Organizational Commitment and Intention to Stay." International Journal of Manpower 29(6). doi: 10.1108/01437720810904194.

Chin, Wynne W. (1998). "The Partial Least Squares Approach for Structural Equation Modeling." Modern Methods for Business Research (April):295-336.

Chinomona, Richard, and Manilall Dhurup. (2014). "The Influence of the Quality of Working Life on Employee Job Satisfaction, Job Commitment and Tenure Intention in the SME Sector in Zimbabwe." South African Journal of Economic and Management Sciences 17(4). doi: 10.4102/sajems.v17i4.296.

Clugston, Michael. (2000). "The Mediating Effects of Multidimensional Commitment on Job Satisfaction and Intent to Leave." Journal of Organizational Behavior 21(4). doi: 10.1002/(SICl)1099-1379(200006)21:4<477::AID-JOB25>3.0.CO;2-7.

Deal, TE, and AA Kennedy. (1982). "Corporate Cultures: The Rites and Rituals of Organizational Life." Reading/Mass: Addison-Wesley (2).

Decotiis, Thomas A., and Timothy P. Summers. (1987). "A Path Analysis of a Model of the Antecedents and Consequences of Organizational Commitment." Human Relations 40(7). doi: 10.1177/001872678704000704.

Dulebohn, James H., and Stephen E. Werling. (2007). "Compensation Research Past, Present, and Future." Human Resource Management Review 17(2). doi: 10.1016/j.hrmr.2007.03.002.

Eliyana, Anis, Syamsul Ma'arif, and Muzakki. (2019). "Job Satisfaction and Organizational Commitment Effect in the Transformational Leadership towards Employee Performance." European Research on Management and Business Economics 25(3). doi: 10.1016/j.iedeen.2019.05.001.

Eliyana, Anis, Ria Mardiana Yusuf, and Koko Prabowo. (2012). "The Influence of Employee's Job Satisfaction Factors on Organizational Commitment." American Journal of Economics 2(4). doi: 10.5923/j.economics.20120001.31.

ElKordy, M. (2013). "Transformational Leadership and Organizational Culture as Predictors of Employees Attitudinal Outcomes." Business Management Dynamics 3(5).

Falk, R. Frank, and Nancy B. Miller. (1992). "A Primer for Soft Modeling." The University of Akron Press (April):80.

Fink, Arlene. (2002). "The Survey Kit ( 2nd Edition ).” Library (800).

Sudirman Widhy, Hendro Yuliantoro, Muhammad Zulkarnain Azwar, Anita Maharani. The Influence of Organizational Culture and Compensation on Organizational Commitment with Job Satisfaction as Mediation 
The Management Journal of BINANIAGA Vol. 06, No.02, December 2021

p-ISSN: 2527 - 4317, e-ISSN: $2580-149 x$

$6^{\text {th }}$ Accreditation Rating: April 04, $2019-$ April 03, 2024

Fiorillo, Damiano, and Nunzia Nappo. (2014). "Job Satisfaction in Italy: Individual Characteristics and Social Relations." International Journal of Social Economics 41(8). doi: 10.1108/IJSE-10-2012-0195.

Fornell, Claes, and David F. Larcker. (1981). "Evaluating Structural Equation Models with Unobservable Variables and Measurement Error." Journal of Marketing Research. doi: $10.2307 / 3151312$.

Fu, Weihui, Satish P. Deshpande, and Xiao Zhao. (2011). "The Impact of Ethical Behavior and Facets of Job Satisfaction on Organizational Commitment of Chinese Employees." Journal of Business Ethics 104(4). doi: 10.1007/s10551-011-0928-4.

Gaertner, Stefan. (1999). "Structural Determinants of Job Satisfaction and Organizational Commitment in Turnover Models." Human Resource Management Review 9(4). doi: 10.1016/S1053-4822(99)00030-3.

Gamlath, G. R. M. (2019). “Job-Satisfaction Factors of Employees in Sri Lankan Export Manufacturing Companies." SJCC Management Research Review 9(1):41. doi: 10.35737/sjccmrr/v9/i1/2019/145545.

Glen, Clayton. (2006). "Key Skills Retention and Motivation: The War for Talent Still Rages and Retention Is the High Ground." Industrial and Commercial Training 38(1). doi: 10.1108/00197850610646034.

Gokce, Beste, Salih Guney, and Alev Katrinli. (2014). “Does Doctors' Perception of Hospital Leadership Style and Organizational Culture Influence Their Organizational Commitment?" Social Behavior and Personality 42(9). doi: 10.2224/sbp.2014.42.9.1549.

Govaerts, Natalie, Eva Kyndt, Filip Dochy, and Herman Baert. (2011). "Influence of Learning and Working Climate on the Retention of Talented Employees." Journal of Workplace Learning 23(1). doi: 10.1108/13665621111097245.

Grant, Robert M. (1991). "The Resource-Based Theory of Competitive Advantage: Implications for Strategy Formulation." California Management Review 33(3). doi: $10.2307 / 41166664$.

Greene, Robert J. (2014). "The Role of Employee Ownership in the Total Rewards Strategy." Compensation \& Benefits Review 46(1). doi: 10.1177/0886368714529919.

Gregson, Terry. (1992). "An Investigation Of The Causal Ordering Of Job Satisfaction And Organizational Commitment In." Behavioral Research in Accounting 4.

Gunlu, Ebru, Mehmet Aksarayli, and Nilüfer Şahin Perçin. (2010). "Job Satisfaction and Organizational Commitment of Hotel Managers in Turkey." International Journal of Contemporary Hospitality Management 22(5). doi: 10.1108/09596111011053819.

Gupta, Nina, and Jason D. Shaw. (2014). "Employee Compensation: The Neglected Area of HRM Research." Human Resource Management Review 24(1). doi: 10.1016/j.hrmr.2013.08.007.

Hashim, Raemah Abdullah, and Rosli Mahmood. (2011). "What Is the State of Job Satisfaction Among Academic Staff At Malaysian Universities?" UNIVERSITI TUN ABDUL RAZAK E-JOURNAL 7(1).

Sudirman Widhy, Hendro Yuliantoro, Muhammad Zulkarnain Azwar, Anita Maharani. The Influence of Organizational Culture and Compensation on Organizational Commitment with Job 
Henseler, Jörg. (2017). "Bridging Design and Behavioral Research With Variance-Based Structural Equation Modeling." Journal of Advertising 46(1):178-92. doi: 10.1080/00913367.2017.1281780.

Hofstede, Geert, and Michael Harris Bond. (1988). "The Confucius Connection: From Cultural Roots to Economic Growth." Organizational Dynamics 16(4). doi: 10.1016/0090-2616(88)90009-5.

Horwitz, Frank M., Chan Teng Heng, and Hesan Ahmed Quazi. (2003). "Finders, Keepers? Attracting, Motivating and Retaining Knowledge Workers." Human Resource Management Journal 13(4). doi: 10.1111/j.1748-8583.2003.tb00103.x.

Ilham, Romi. (2017). "The Impact of Organizational Culture and Leadership Style on Job Satisfaction and Employee Performance." Journal of Advanced Management Science. doi: 10.18178/joams.6.1.50-53.

Islam, Talat, Saif ur Rehman Khan, Ungku Norulkamar Ungku Bt Ahmad, and Ishfaq Ahmed. (2013). "Organizational Learning Culture and Leader-Member Exchange Quality: The Way to Enhance Organizational Commitment and Reduce Turnover Intentions." Learning Organization 20(4-5). doi: 10.1108/TLO-12-2012-0079.

Iverson, Roderick D., and Parimal Roy. (1994). "A Causal Model of Behavioral Commitment: Evidence From a Study of Australian Blue-Collar Employees." Journal of Management 20(1). doi: 10.1177/014920639402000102.

Jalalkamali, Mohammad, Anees Janee Ali, Sunghyup Sean Hyun, and Davoud Nikbin. (2016). "Relationships between Work Values, Communication Satisfaction, and Employee Job Performance: The Case of International Joint Ventures in Iran." Management Decision 54(4). doi: 10.1108/MD-01-2015-0003.

Johnson, Richard D., Steven Hornik, and Eduardo Salas. (2008). "An Empirical Examination of Factors Contributing to the Creation of Successful E-Learning Environments." International Journal of Human Computer Studies 66(5). doi: 10.1016/j.ijhcs.2007.11.003.

Joung, Hyun Woo, Ben K. Goh, Lynn Huffman, Jingxue Jessica Yuan, and James Surles. (2015). "Investigating Relationships between Internal Marketing Practices and Employee Organizational Commitment in the Foodservice Industry." International Journal of Contemporary Hospitality Management 27(7). doi: 10.1108/IJCHM-052014-0269.

Judge, Timothy A., Carl J. Thoresen, Joyce E. Bono, and Gregory K. Patton. (2001). "The Job Satisfaction-Job Performance Relationship: A Qualitative and Quantitative Review." Psychological Bulletin 127(3). doi: 10.1037/0033-2909.127.3.376.

Kennedy, Kate, and Vanessa Gray. (2014). "Employee Job Satisfaction and Engagement- The Road to Economic Recovery: A Research Report by the Society for Human Resource Management (SHRM)." Society for Human Resource Management.

King, Ceridwyn, Debra Grace, and Daniel C. Funk. (2013). "Erratum: Employee Brand Equity: Scale Development and Validation (Journal of Brand Management (2013) 20 (350-354))." Journal of Brand Management 20(4).

Kline, R. B.(2015). TXTBK Principles and Practices of Structural Equation Modelling Ed. $4^{* * *}$.

Sudirman Widhy, Hendro Yuliantoro, Muhammad Zulkarnain Azwar, Anita Maharani. The Influence of Organizational Culture and Compensation on Organizational Commitment with Job Satisfaction as Mediation 
The Management Journal of BINANIAGA Vol. 06, No.02, December 2021

p-ISSN: 2527-4317, e-ISSN: $2580-149 x$

$6^{\text {th }}$ Accreditation Rating: April 04, $2019-$ April 03, 2024

Koohang, Alex, Joanna Paliszkiewicz, and Jerzy Goluchowski. (2017). "The Impact of Leadership on Trust, Knowledge Management, and Organizational Performance: A Research Model." Industrial Management and Data Systems 117(3):521-37. doi: 10.1108/IMDS-02-2016-0072.

Köse, Serap Durukan, and Tuncay Köse. (2017). "The Effect of Job Satisfaction on Organizational Commitment of Healthcare Personnel." IOSR Journal of Business and Management 19(01):54-59. doi: 10.9790/487x-1901025459.

Lapointe, Émilie, Christian Vandenberghe, and Jean Sébastien Boudrias. (2013). "Psychological Contract Breach, Affective Commitment to Organization and Supervisor, and Newcomer Adjustment: A Three-Wave Moderated Mediation Model." Journal of Vocational Behavior 83(3). doi: 10.1016/j.jvb.2013.07.008.

Lazarus, Harold, and Edward E. Lawler. (1972). "Pay and Organizational Effectiveness: A Psychological View." Industrial and Labor Relations Review 25(3). doi: 10.2307/2521335.

Limerick, David;cunnington, Bert;crowther, Frank. (1998). "Managing the New Organisation."

Locke, E. A. (1976). "The Nature and Causes of Job Satisfaction." in Handbook of Industrial and Organizational Psychology.

Lok, Peter, and John Crawford. (2001). "Antecedents of Organizational Commitment and the Mediating Role of Job Satisfaction." Journal of Managerial Psychology 16(8):594-613. doi: 10.1108/EUM0000000006302.

Lum, Lillie, John Kervin, Kathleen Clark, Frank Reid, and Wendy Sirola. (1998). "Explaining Nursing Turnover Intent: Job Satisfaction, Pay Satisfaction, or Organizational Commitment?" Journal of Organizational Behavior 19(3). doi: 10.1002/(SICI)1099-1379(199805)19:3<305::AID-JOB843>3.0.CO;2-N.

Lund, Daulatram B. (2003). "Organizational Culture and Job Satisfaction." Journal of Business and Industrial Marketing 18(2-3):219-36. doi: 10.1108/0885862031047313.

Luthans, Fred. (2012). Organizational Behavior an Evidence-Based Approach 12th Edition.

Mabaso, Calvin Mzwenhlanhla, and Bongani Innocent Dlamini. (2017). "Impact of Compensation and Benefits on Job Satisfaction." Research Journal of Business Management 11(2). doi: 10.3923/rjbm.2017.80.90.

Makena Muguongo, Mary. (2015). "Effects of Compensation on Job Satisfaction Among Secondary School Teachers in Maara Sub - County of Tharaka Nithi County, Kenya." Journal of Human Resource Management 3(6). doi: 10.11648/j.jhrm.20150306.11.

Malhotra, Neeru, Pawan Budhwar, and Peter Prowse. (2007). "Linking Rewards to Commitment: An Empirical Investigation of Four UK Call Centres." International Journal of Human Resource Management 18(12). doi: 10.1080/09585190701695267.

Sudirman Widhy, Hendro Yuliantoro, Muhammad Zulkarnain Azwar, Anita Maharani. The Influence of Organizational Culture and Compensation on Organizational Commitment with Job 
Malthis, Robert L., and John H. Jackson. (2006). "Human Resource Management (Manajemen Sumber Daya Manusia), Edisi Kesepuluh, Terjemahan: Diana Angelica." Penerbit: Salembs Empat, Jakarta.

Masia, Uanda, and Jaco Pienaar. (2011). "Unravelling Safety Compliance in the Mining Industry: Examining the Role of Work Stress, Job Insecurity, Satisfaction and Commitment as Antecedents." SA Journal of Industrial Psychology 37(1). doi: 10.4102/sajip.v37i1.937.

Mathieu, John E., and Karin Hamel. (1989). "A Causal Model of the Antecedents of Organizational Commitment among Professionals and Nonprofessionals." Journal of Vocational Behavior 34(3):299-317. doi: 10.1016/0001-8791(89)90022-5.

Mathieu, John E., and Dennis M. Zajac. (1990). "A Review and Meta-Analysis of the Antecedents, Correlates, and Consequences of Organizational Commitment." Psychological Bulletin 108(2). doi: 10.1037/0033-2909.108.2.171.

McCaul, Harriette S., Verlin B. Hinsz, and Kevin D. McCaul. (1995). "Assessing Organizational Commitment: An Employee's Global Attitude toward the Organization." The Journal of Applied Behavioral Science 31(1). doi: $10.1177 / 0021886395311008$.

McLean, Ephraim R., Stanley J. Smits, and John R. Tanner. (1996). "The Importance of Salary on Job and Career Attitudes of Information Systems Professionals." Information and Management 30(6). doi: 10.1016/S0378-7206(96)01059-2.

Mehra, Payal, and Catherine Nickerson. (2019). "Organizational Communication and Job Satisfaction: What Role Do Generational Differences Play?" International Journal of Organizational Analysis 27(3). doi: 10.1108/IJOA-12-2017-1297.

Meyer, John P., and Nathalie J. Allen. (1997). "'Commitment in the Workplace, Theory, Research and Application', Thousand Oaks, Sage Publications, 151 p. $\square$ Chapitre 6." Sage Publications.

Meyer, John P., and Lynne Herscovitch. (2001). "Commitment in the Workplace: Toward a General Model." Human Resource Management Review 11(3). doi: 10.1016/S1053-4822(00)00053-X.

Meyer, John P., and Natalya M. Parfyonova. (2010). "Normative Commitment in the Workplace: A Theoretical Analysis and Re-Conceptualization." Human Resource Management Review 20(4). doi: 10.1016/j.hrmr.2009.09.001.

Meyer, John P., David J. Stanley, Lynne Herscovitch, and Laryssa Topolnytsky. (2002). "Affective, Continuance, and Normative Commitment to the Organization: A MetaAnalysis of Antecedents, Correlates, and Consequences." Journal of Vocational Behavior 61(1). doi: 10.1006/jvbe.2001.1842.

Mitchell, Terence R., and Thomas W. Lee. (2001). "5. The Unfolding Model of Voluntary Turnover and Job Embeddedness: Foundations for a Comprehensive Theory of Attachment." Research in Organizational Behavior 23. doi: 10.1016/S01913085(01)23006-8.

Mosadeghrad, Ali Mohammad, Ewan Ferlie, and Duska Rosenberg. (2008). "A Study of the Relationship between Job Satisfaction, Organizational Commitment and Turnover Intention among Hospital Employees." Health Services Management Research 21(4). doi: 10.1258/hsmr.2007.007015.

Sudirman Widhy, Hendro Yuliantoro, Muhammad Zulkarnain Azwar, Anita Maharani. The Influence of Organizational Culture and Compensation on Organizational Commitment with Job Satisfaction as Mediation 
The Management Journal of BINANIAGA Vol. 06, No.02, December 2021

p-ISSN: 2527 - 4317, e-ISSN: $2580-149 x$

$6^{\text {th }}$ Accreditation Rating: April 04, $2019-$ April 03, 2024

Mowday, Richard T., Richard M. Steers, and Lyman W. Porter. (1979). "The Measurement of Organizational Commitment." Journal of Vocational Behavior 14(2). doi: 10.1016/0001-8791(79)90072-1.

Mueller, Charles W., Jean E. Wallace, and James L. Price. (1992). "Employee Commitment:Resolving Some Issues." Work and Occupations 19(3). doi: 10.1177/0730888492019003001.

Mustafa, Ghulam, Muhammad Ilyas, and Abul Rehman. (2016). "Do the Employees ' Job Satisfaction Interferes Organizational Culture and Affective Commitment Relationship : Test of ... Phd Thesis View Project." Journal of Applied Environmental and Biological Sciences 6(5).

Natasha Fogaça, and Francisco Antônio Coelho Junior. (2016). “Is 'Happy Worker' More Productive." Management Studies 4(4). doi: 10.17265/2328-2185/2016.04.002.

Norris, Dwight R., and Robert E. Niebuhr. (1984). "Professionalism, Organizational Commitment and Job Satisfaction in an Accounting Organization." Accounting, Organizations and Society 9(1). doi: 10.1016/0361-3682(84)90029-1.

Owsley, K., and R. Lindrooth. (2020). "ORGANIZATIONAL BEHAVIOR AND MANAGEMENT." Health Services Research 55(S1). doi: 10.1111/14756773.13492 .

Peate, lorwerth C. (1966). "Language, Culture And Society." Folk Life 4(1). doi: $10.1179 / 043087766798242331$.

Penny Wan, Yim King, Ip Kin Anthony Wong, and Weng Hang Kong. (2014). "Student Career Prospect and Industry Commitment: The Roles of Industry Attitude, Perceived Social Status, and Salary Expectations." Tourism Management 40. doi: 10.1016/j.tourman.2013.05.004.

Pillay, Rubin. (2009). "Retention Strategies for Professional Nurses in South Africa." Leadership in Health Services 22(1).

Porter, Lyman W., Richard M. Steers, Richard T. Mowday, and Paul V. Boulian. (1974). "Organizational Commitment, Job Satisfaction, and Turnover among Psychiatric Technicians." Journal of Applied Psychology 59(5). doi: 10.1037/h0037335.

Price, James L., and Charles W. Mueller. (1983). "Professional Turnover: The Case of Nurses." Möbius: A Journal for Continuing Education Professionals in Health Sciences 3(2). doi: 10.1002/chp.4760030220.

Puni, Albert, Ibrahim Mohammed, and Emmanuel Asamoah. (2018). "Transformational Leadership and Job Satisfaction: The Moderating Effect of Contingent Reward." Leadership and Organization Development Journal 39(4):522-37. doi: 10.1108/LODJ-11-2017-0358.

Qazi, Sayeeduzzafar, Mohammad Saleh Miralam, and Pretty Bhalla. (2017). "Organizational Culture and Job Satisfaction: A Study of Organized Retail Sector." Journal of Business and Retail Management Research 12(1). doi: 10.24052/jbrmr/v12is01/ocajsasoors.

Rashid, Md Zabid Abdul, Murali Sambasivan, and Juliana Johari. (2003). "The Influence of Corporate Culture and Organisational Commitment on Performance." Journal of Management Development 22(7-8). doi: 10.1108/02621710310487873.

Sudirman Widhy, Hendro Yuliantoro, Muhammad Zulkarnain Azwar, Anita Maharani. The Influence of Organizational Culture and Compensation on Organizational Commitment with Job 
Rawashdeh, Adnan, Ahmed Al-Saraireh, and Gassan Obeidat. (2015). "Does Organizational Culture Matter for Job Satisfaction in Jordanian Private Aviation Companies?" International Journal of Information, Business and Management 7(2).

Raykov, Tenko. 1997. "Estimation of Composite Reliability for Congeneric Measures." Applied Psychological Measurement. doi: 10.1177/01466216970212006.

Rehman, Shams-Ur, Aamer Shareef, Arfan Mahood, and Amir Ishaque. 2012. "Perceived Leadership Styles and Organizational Commitment." Interdisciplinary Journal of Contemporary Research in Business 4.

Rianaa, I. Gede, and I. Wayan Pradnyantha Wirasedanaa. (2016). "The Effect of Compensation on Organisational Commitment and Employee Performance with the Labour Union as the Moderating Variable." Scientific Journal of PPI-UKM 3(2).

Riketta, Michael. (2002). "Attitudinal Organizational Commitment and Job Performance: A Meta-Analysis." Journal of Organizational Behavior 23(3). doi: 10.1002/job.141.

Robbins, S. P., T. A. Judge, Aletta Odendaal, and G. Roodt. (2016). Organisational Behaviour: Global and Southern African Perspectives.

Robbins, Stephen P., and Mary Coulter. (2012). Management Eleventh Edition. Vol. 6.

Robbins, Stephen P., and Timothy A. Judge. (2017). "Organizational Behavior, Seventeenth Edition, Global Edition." Pearson Education Limited.

Rojuaniah. (2017). "Kepuasan Kerja Sebagai Pendorong Komitmen Organisasional Dan Organizational Citizenship Behavior (OCB)." Jurnal Ekonomi 8(2):222-31.

Rubel, Mohammad Rabiul Basher, Nadia Newaz Rimi, Mohd Yusoff Yusliza, and Daisy Mui Hung Kee. (2018). "High Commitment Human Resource Management Practices and Employee Service Behaviour: Trust in Management as Mediator." IIMB Management Review 30(4). doi: 10.1016/j.iimb.2018.05.006.

Russ, Frederick A., and Kevin M. McNeilly. (1995). "Links among Satisfaction, Commitment, and Turnover Intentions: The Moderating Effect of Experience, Gender, and Performance." Journal of Business Research 34(1). doi: 10.1016/01482963(94)00042-D.

Sackman, Sonja. (1991). Culture Knowledge in Organizations - Exploring the Collective Mind. SAGE publication.

Salisu, Jamilu B., Ezekiel Chinyio, and Subashini Suresh. (2015). "The Impact of Compensation on the Job Satisfaction of Public Sector Construction Workers of Jigawa State of Nigeria." The Business and Management Review 6(4).

Samad, Sarminah. (2005). "Unraveling the Organizational Commitment and Job Performance Relationship: Exploring the Moderating Effect of Job Satisfaction." The Business Review, Cambridge 4(2).

Saman, Anton. (2020). "Effect of Compensation on Employee Satisfaction and Employee Performance." International Journal of Economics, Business and Accounting Research (IJEBAR) 4(01):185-90. doi: 10.29040/ijebar.v4i01.947.

Sami, Pirzada, Ullah Sabri, Muhammad Ilyas, and Zahra Amjad. (2011). "Organizational Culture and Its Impact on the Job Satisfaction of the University Teachers of Lahore

Sudirman Widhy, Hendro Yuliantoro, Muhammad Zulkarnain Azwar, Anita Maharani. The Influence of Organizational Culture and Compensation on Organizational Commitment with Job Satisfaction as Mediation 
The Management Journal of BINANIAGA Vol. 06, No.02, December 2021

p-ISSN: 2527 - 4317, e-ISSN: $2580-149 x$

$6^{\text {th }}$ Accreditation Rating: April 04, $2019-$ April 03, 2024

Pirzada Sami Ullah Sabri." International Journal of Business and Social Science 2(24).

Sartono, Hasan, and Mauliah Ardhani. n.d. "Work Engagement, Intrinsic Motivation and Job Satisfaction among Employees of A Coal Mining Company in South Borneo." 8(2):107-22.

Schein, Edgar. (2017). "Organizational Culture and Leadership Organizational Culture and Leadership." Wiley \& Sons, Inc. (Idd).

Sekaran Uma; Bougie Roger. (2016). Research Methods for Business: A Skill Building Approach.

Senjaya, Veny, and Rina Anindita. (2020). "The Role of Transformational Leadership and Organizational Culture Towards Organizational Commitment Through Job Satisfaction Among Mining Industry Employees." Jurnal Aplikasi Manajemen 18(4):767-82. doi: 10.21776//ub.jam.2020.018.04.15.

Shah, Syed Munir Ahmed, Mohammad Salih Memon, and Minhon Khan Laghari. (2011). 'The Impact of Organizational Culture on the Employees' Job Satisfaction: A Study of Faculty Members of Public Sector Universities of Pakistan." Interdisciplinary Journal of Contemporary Research In Business 3(8).

Sigler, K. J. (1999). "Challenges of Employee Retention." Management Research News 22(10). doi: 10.1108/01409179910781823.

Sikorska-Simmons, Elzbieta. (2006). "Organizational Culture and Work-Related Attitudes among Staff in Assisted Living." Journal of Gerontological Nursing 32(2). doi: 10.3928/0098-9134-20060201-07.

Silitonga, Nelson, Dewiana Novitasari, Didi Sutardi, Ardian Sopa, Masduki Asbari, Yayah Yulia, Joko Supono, and Ahmad Fauji. (2020). "The Relationship of Transformational Leadership, Organizational Justice and Organizational Commitment: A Mediation Effect of Job Satisfaction." Journal of Critical Reviews 7(19):89-108.

Silverthorne, Colin. (2004). "The Impact of Organizational Culture and PersonOrganization Fit on Organizational Commitment and Job Satisfaction in Taiwan." Leadership \& Organization Development Journal 25(7). doi: $10.1108 / 01437730410561477$.

Sinem AYDOGDU; Baris ASIKGIL. (2011). "An Empirical Study of the Relationship Among Job Satisfaction , Organizational Commitment and Turnover Intention." International Review of Management and Marketing 1(3):43-53.

Sony, Michael, and Nandakumar Mekoth. (2016). "The Relationship between Emotional Intelligence, Frontline Employee Adaptability, Job Satisfaction and Job Performance." Journal of Retailing and Consumer Services 30. doi: 10.1016/j.jretconser.2015.12.003.

Supriyadi, Andhi, Anwar Sanusi, and Abdul Manan. (2017). "A Study on the Performance of Manufacturing Employees: Organizational Culture, Compensation, Organizational Commitment, and Organizational Citizenship Behavior." European Journal of Business and Management 9(6):32-43.

Sudirman Widhy, Hendro Yuliantoro, Muhammad Zulkarnain Azwar, Anita Maharani. The Influence of Organizational Culture and Compensation on Organizational Commitment with Job 
Taormina, Robert J. (1999). "Predicting Employee Commitment and Satisfaction: The Relative Effects of Socialization and Demographics." International Journal of Human Resource Management 10(6). doi: 10.1080/095851999340125.

Terera, Sharon Ruvimbo, and Hlanganipai Ngirande. (2014). "The Impact of Rewards on Job Satisfaction and Employee Retention." Mediterranean Journal of Social Sciences 5(1). doi: 10.5901/mjss.2014.v5n1p481.

Towers, David. (2006). "An Investigation into Whether Organisational Culture Is Directly Linked to Motivation and Performance through Looking at Google Inc ." Word Journal Of The International Linguistic Association 2006.

Trice, Harrison M., Richard T. Mowday, Lyman W. Porter, and Richard M. Steers. (1984). "Employee-Organization Linkages: The Psychology of Commitment, Absenteeism, and Turnover." Contemporary Sociology 13(1). doi: 10.2307/2068333.

Tushman, Michael L. (1997). "Winning through Innovation." Strategy \& Leadership 25(4).

Uttal, Bro. (1983). "The Corporate Culture Vultures." Fortune.

Valaei, Naser, Sajad Rezaei, and Maryam Emami. (2016). "Impact of Exploitative Learning Strategy on Malaysian SMEs' Creativity and Innovation Capabilities." International Journal of Management and Enterprise Development 15(4). doi: 10.1504/IJMED.2016.079853.

Ven, Andrew H. Van, Thomas J. Peters, and Robert H. Waterman. (1983). "In Search of Excellence: Lessons from America's Best-Run Companies." Administrative Science Quarterly 28(4). doi: 10.2307/2393015.

Vincent, Melvin J., Frederick Herzberg, Bernard Mausner, and Barbara Bloch Snyderman. (1960). "The Motivation to Work." American Sociological Review 25(2). doi: $10.2307 / 2092643$.

Werts, C. E., D. R. Rock, R. L. Linn, and K. G. Jöreskog. (1978). "A General Method of Estimating the Reliability of a Composite." Educational and Psychological Measurement. doi: 10.1177/001316447803800412.

Williams, Larry J., and John T. Hazer. (1986). "Antecedents and Consequences of Satisfaction and Commitment in Turnover Models. A Reanalysis Using Latent Variable Structural Equation Methods." Journal of Applied Psychology 71(2). doi: 10.1037/0021-9010.71.2.219.

Yiing, Lee Huey, and Kamarul Zaman Bin Ahmad. (2009). "The Moderating Effects of Organizational Culture on the Relationships between Leadership Behaviour and Organizational Commitment and between Organizational Commitment and Job Satisfaction and Performance." Leadership and Organization Development Journal 30(1):53-86. doi: 10.1108/01437730910927106.

Yildirim, Seda, Ali Acaray, and Burcu Candan. (2016). "The Relationship between Marketing Culture and Organizational Commitment." World Journal of Entrepreneurship, Management and Sustainable Development 12(1). doi: 10.1108/wjemsd-08-2015-0035.

Sudirman Widhy, Hendro Yuliantoro, Muhammad Zulkarnain Azwar, Anita Maharani. The Influence of Organizational Culture and Compensation on Organizational Commitment with Job Satisfaction as Mediation 
The Management Journal of BINANIAGA Vol. 06, No.02, December 2021

p-ISSN: 2527 - 4317, e-ISSN: $2580-149 x$

$6^{\text {th }}$ Accreditation Rating: April 04, 2019-April 03, 2024

Yousef, Darwish A. (2000). "Organizational Commitment: A Mediator of the Relationships of Leadership Behavior with Job Satisfaction and Performance in a Non-Western Country." Journal of Managerial Psychology 15(1). doi: 10.1108/02683940010305270.

Zayas-ortiz, MaríA, Ernesto Rosario, Eulalia Marquez, and Pablo ColóN Gruñeiro. (2015). "Relationship between Organizational Commitments and Organizational Citizenship Behaviour in a Sample of Private Banking Employees." International Journal of Sociology and Social Policy 35. doi: 10.1108/IJSSP-02-2014-0010.

Sudirman Widhy, Hendro Yuliantoro, Muhammad Zulkarnain Azwar, Anita Maharani. The Influence of Organizational Culture and Compensation on Organizational Commitment with Job 